OPEN ACCESS

Edited by:

JeanSébastien Silvestre,

Institut national de la santé

et de la recherche

médicale, France

Reviewed by:

Elisa Avolio,

University of Bristol,

United Kingdom

Rosalinda Madonna,

"G. D’Annunzio" University, Italy

*Correspondence:

Georgina M. Ellison-Hughes georgina.ellison@kcl.ac.uk;

Jun Jie Tan

jjtan@usm.my

Specialty section:

This article was submitted to

Cardiovascular Biologics and

Regenerative Medicine,

a section of the journal

Frontiers in Cardiovascular Medicine

Received: 15 May 2017

Accepted: 29 June 2017

Published: 17 July 2017

Citation:

Leong YY, Ng WH, Ellison-

Hughes GM and Tan JJ (2017)

Cardiac Stem Cells for Myocardial

Regeneration: They Are Not Alone.

Front. Cardiovasc. Med. 4:47.

doi: 10.3389/fcrm.2017.00047

\section{Cardiac Stem Cells for Myocardial Regeneration: They Are Not Alone}

\author{
Yin Yee Leong ${ }^{1}$, Wai Hoe $\mathrm{Ng}^{1}$, Georgina M. Ellison-Hughes ${ }^{2,3 *}$ and Jun Jie Tan ${ }^{1,2,3 *}$ \\ ${ }^{1}$ Advanced Medical and Dental Institute, Universiti Sains Malaysia, Penang, Malaysia, ${ }^{2}$ Centre for Human and \\ Aerospace Physiological Sciences, King's College London, London, United Kingdom, ${ }^{3}$ Centre for Stem Cells and \\ Regenerative Medicine, King's College London, London, United Kingdom
}

Heart failure is the number one killer worldwide with $50 \%$ of patients dying within 5 years of prognosis. The discovery of stem cells, which are capable of repairing the damaged portion of the heart, has created a field of cardiac regenerative medicine, which explores various types of stem cells, either autologous or endogenous, in the hope of finding the "holy grail" stem cell candidate to slow down and reverse the disease progression. However, there are many challenges that need to be overcome in the search of such a cell candidate. The ideal cells have to survive the harsh infarcted environment, retain their phenotype upon administration, and engraft and be activated to initiate repair and regeneration in vivo. Early bench and bedside experiments mostly focused on bone marrow-derived cells; however, heart regeneration requires multiple coordinations and interactions between various cell types and the extracellular matrix to form new cardiomyocytes and vasculature. There is an observed trend that when more than one cell is coadministered and cotransplanted into infarcted animal models the degree of regeneration is enhanced, when compared to single-cell administration. This review focuses on stem cell candidates, which have also been tested in human trials, and summarizes findings that explore the interactions between various stem cells in heart regenerative therapy.

Keywords: myocardial regeneration, cardiac stem and progenitor cells, synergy, interactions, cell therapy, cardiac tissue engineering

\section{INTRODUCTION}

Cardiovascular disease remains the number one, non-communicable killer disease, which recorded a mortality rate of 17.5 million in 2012, and was accounted for $46.2 \%$ of all reported deaths worldwide in 2014 (1). Myocardial infarction (MI) is a common cause of heart failure (HF) due to a consequence of partial or complete occlusion of the coronary artery, which diminishes the delivery of oxygen and nutrient supply to the myocardium where the vessel serves (2). Approximately $25 \%$ of myocardial infarcted patients suffer from severe left ventricular dysfunction and are at risk of progressive heart remodeling (3). Conventional pharmacological approaches with drugs, such as thrombolytic agent, $\beta$-blocker, and angiotensin-converting enzyme inhibitor, is often the first non-invasive treatment option offered to patients. However, in more severe cases, ST-elevated myocardial infarction (STEMI), a more invasive balloon angioplasty, and stent insertion may be recommended to achieve myocardial reperfusion. Highly invasive coronary artery bypass grafting 
procedure is only recommended if severe, irreversible coronary occlusion is evident. These approaches had shown to alleviate the symptoms of the disease and improve the patients' quality of life. Nevertheless, none of these therapies were able to remove the fibrotic scar or replace the lost myocardium with new functional cardiomyocytes. The presence of the akinetic tissue restricts the overall cardiac performance, forcing the remaining myocytes to increase contractility to maintain adequate cardiac output. These events trigger abrupt alterations in cardiac architecture and cause cardiomyocyte hypertrophy, further myocyte loss, thinning of the ventricular wall, weakening of contractility, and an eventual cease in function of the cardiomyocytes (4). To date, heart transplantation is the only curative option. Although there are survivors from successful heart transplantations, the long waiting time, high patient-to-donor ratio, high incidence of post-procedural complications, and limited number of transplantable hearts prompt an urgent need for an alternative solution. Stem cell-based therapies are fast becoming an attractive and highly promising treatment for heart disease and failure. The most common types of stem cell candidates, which had been tested in clinical trials thus far, are derived mainly from the bone marrow. In this review, we will discuss the basic discovery and current progress of the candidate cells in human cardiac regenerative therapy, and the potential to combine multiple cell types for regenerating complex components that make up the myocardium (Figure 1). Finally, we touch on an emerging prospective application in heart tissue engineering.

\section{BONE MARROW-DERIVED MONONUCLEAR AND HEMATOPOIETIC STEM CELLS (HSCs)}

The discovery of recipient-derived cardiomyocytes in sexmismatched donor hearts after bone marrow transplants spiked the interest of using bone marrow cells for cardiac cell therapy (5-7). Bone marrow mononuclear cells (BMNCs) were the first hematopoietic cells selected for this purpose, because of their availability and feasibility to be isolated from patients through bone marrow aspiration (8). In fact, the in vitro procedure involved minimal manipulation for clinical transplantation, making it the most favorite cell candidate in initial cardiac repair clinical trials. Nevertheless, most clinical studies observed a marginal, yet clinically significant, improvement in cardiac function after injection with BMNCs (Table 1). Despite evidences that showed the BMNCs contribute to angiogenesis (9) and neovascularization (10) by secreting paracrine factors, their capability of cardiomyogenic differentiation in vivo remains skeptical. The earliest study, where lineage-negative $\left(\mathrm{Lin}^{-}\right), \mathrm{c}$-kit-positive $\left(\mathrm{c}-\mathrm{kit}^{+}\right)$, EGFP + HSCs were injected into the contracting wall bordering the infarct in mice, showed newly formed myocardium, comprised cardiomyocytes and vasculature, occupying $68 \%$ of the infarcted portion of the ventricle 9 days after transplanting the bone marrow cells (11). These findings failed to be replicated by others. Murry et al. (12) tracked the fate of HSCs (c-kit $\left.{ }^{+}, \mathrm{Lin}^{-}\right)$ after 145 transplants into normal and injured adult mouse hearts

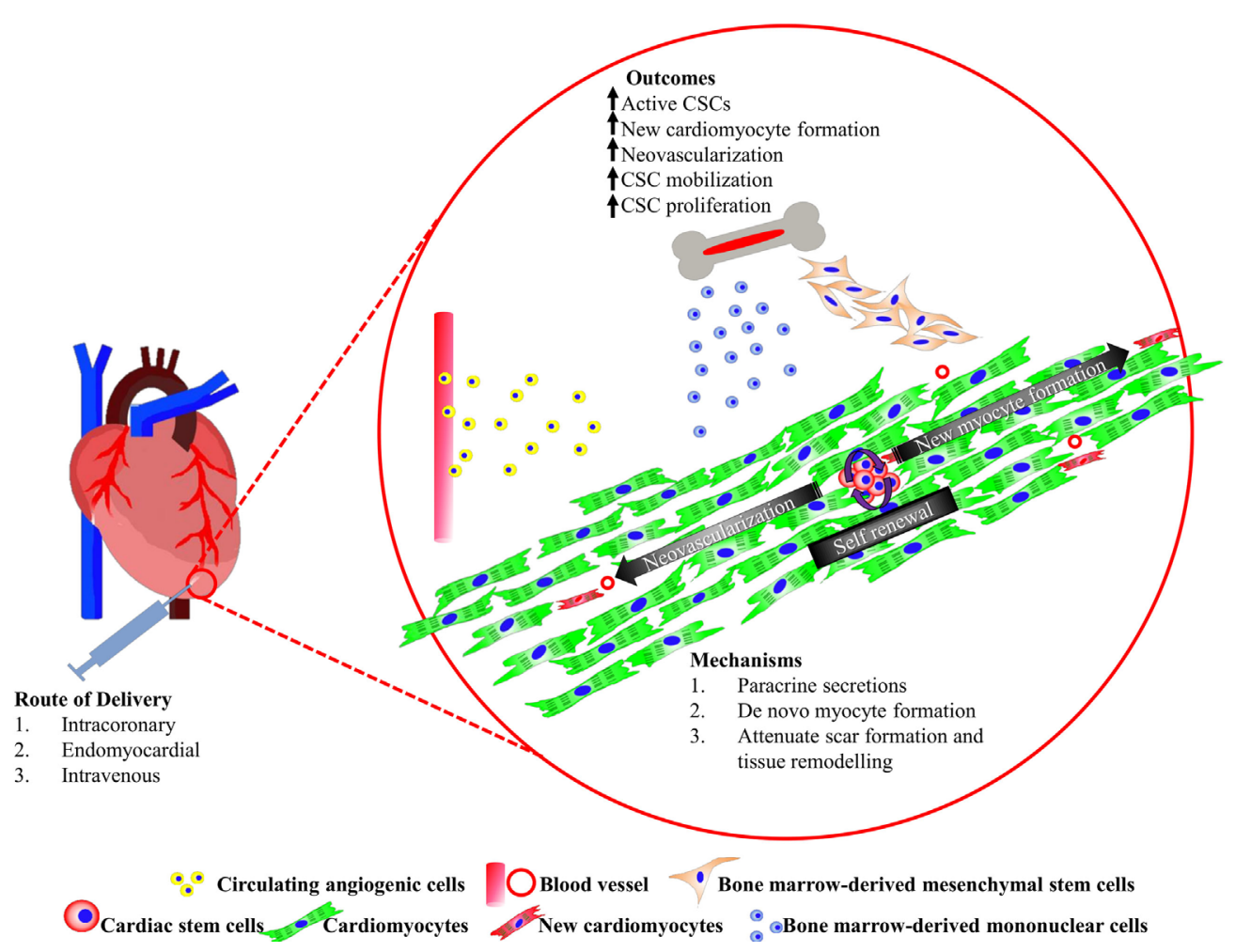

FIGURE 1 | Summary of cardiac stem/progenitor cells and their interaction with bone marrow-derived cells promoting heart regeneration. 
TABLE 1 | List of clinical trials using bone marrow mononuclear cells.

\begin{tabular}{|c|c|c|c|c|c|c|c|c|}
\hline \multirow[t]{2}{*}{ Study } & \multirow{2}{*}{$\begin{array}{l}\text { Number of } \\
\text { patients }\end{array}$} & \multirow[t]{2}{*}{ Type of patients } & \multirow{2}{*}{$\begin{array}{l}\text { Duration } \\
\text { (months) }\end{array}$} & \multirow[t]{2}{*}{ Imaging modality } & \multicolumn{3}{|c|}{ Changes in left ventricular ejection fraction (LVEF) } & \multirow[t]{2}{*}{ Reference } \\
\hline & & & & & Placebo & Treated & $\%$ Changes in LVEF (treated) & \\
\hline TOPCARE-AMI (2002) & 20 & Acute Ml & 4 & $\begin{array}{l}\text { LV angiography } \\
\text { Echocardiography } \\
\text { PET }\end{array}$ & $51.0 \pm 10.0-53.5 \pm 7.9 \%$ & $51.6 \pm 9.6-60.1 \pm 8.6 \%$ & $+8.5^{\star}$ & (14) \\
\hline TOPCARE-AMI (2004) ${ }^{\mathrm{a}}$ & 59 & Acute Ml & 4 & $\begin{array}{l}\text { LV angiography } \\
\text { Echocardiography } \\
\text { MRI }\end{array}$ & $50.0 \pm 10.0-58.0 \pm 10.0 \%$ & $49.0 \pm 10.0-57.0 \pm 10.0 \%$ & $+8^{*}$ & (15) \\
\hline BOOST (2004) & 60 & STEMI & 6 & Cardiac MRI & $51.3 \pm 9.3-52.0 \pm 12.4 \%$ & $50.0 \pm 10.0-56.7 \pm 12.5 \%$ & $+6.7^{\star}$ & (16) \\
\hline BOOST (2006) & 60 & STEMl & 18 & Cardiac MRI & $51.3 \pm 9.3-54.4 .0 \pm 13.0 \%$ & $50.0 \pm 10.0-55.9 \pm 14.7 \%$ & +5.9 & $(17)$ \\
\hline REPAIR-AMI (2006) & 204 & Acute Ml & 4 & LV angiography & $46.9 \pm 10.4-49.9 \pm 13.0 \%$ & $48.3 \pm 9.2-53.8 \pm 10.2 \%$ & $+10.5^{\star}$ & (18) \\
\hline LEUVEN-AMI (2006) & 67 & STEMI & 4 & $\begin{array}{l}\text { MRI } \\
\text { PET } \\
\text { Echocardiography }\end{array}$ & $46.9 \pm 8.2-49.1 \pm 10.7$ & $48.5 \pm 7.2-51.8 \pm 8.8 \%$ & +3.3 & (19) \\
\hline ASTAMI (2006) & 97 & STEMI & 6 & $\begin{array}{l}\text { Echocardiography } \\
\text { SPECT } \\
\text { MRI }\end{array}$ & $46.9 \pm 9.6-49.0 \pm 9.5 \%$ & $45.7 \pm 9.4-48.8 \pm 10.7 \%$ & +3.1 & (20) \\
\hline TCT-STAMI (2006) & 20 & Acute Ml & 6 & $\begin{array}{l}\text { Echocardiography } \\
\text { SPECT }\end{array}$ & $58.2 \pm 7.5-56.3 \pm 3.5 \%$ & $53.8 \pm 9.2-58.6 \pm 9.9 \%$ & $+4.8^{*}$ & (21) \\
\hline TOPCARE-CHD (2007) & 121 & $\begin{array}{l}\text { Chronic post-infarction } \\
\text { HF }\end{array}$ & 3 & LV angiography & $\mathrm{N} / \mathrm{A}$ & $39.9 \pm 11.4-41.7 \pm 11.9 \%$ & $+1.8^{*}$ & (22) \\
\hline Gowdak (2008) & 10 & $\begin{array}{l}\text { Severe coronary artery } \\
\text { disease }\end{array}$ & 12 & $\begin{array}{l}\text { MRI } \\
\text { Echocardiography }\end{array}$ & $\mathrm{N} / \mathrm{A}$ & $63.0 \pm 14.0-67.0 \pm 13.0 \%$ & +4 & (23) \\
\hline FINCELL (2008) & 80 & STEMI & 6 & $\begin{array}{l}\text { Echocardiography } \\
\text { LV angiography }\end{array}$ & $57.0 \pm 10.0-56.0 \pm 10.0 \%$ & $56.0 \pm 10.0-60.0 \pm 8.0 \%$ & $+4^{*}$ & (24) \\
\hline HEBE (2008) & 26 & Acute Ml & 12 & MRI & N/A & $45.0 \pm 6.3-47.2 \pm 6.5 \%$ & $+2.2^{*}$ & (25) \\
\hline $\mathrm{BOOST}(2009)^{\mathrm{a}}$ & 60 & STEMI & 61 & cMRI & $51.3 \pm 9.3-48.1 \pm 12.9 \%$ & $50.0 \pm 10.0-47.5 \pm 16.7 \%$ & -2.5 & (26) \\
\hline ASTAMI (2009) ${ }^{a}$ & 100 & STEMI & 36 & $\begin{array}{l}\text { Echocardiography } \\
\text { MRI }\end{array}$ & $46.9 \pm 9.6-46.8 \pm 8.6 \%$ & $45.7 \pm 9.4-47.5 \pm 9.0 \%$ & +1.8 & (27) \\
\hline REGENT (2009) & 200 & STEMI & 6 & $\begin{array}{l}\text { MRI } \\
\text { Echocardiography } \\
\text { LV angiography }\end{array}$ & $\begin{array}{l}\mathrm{N} / \mathrm{A} \\
\mathrm{N} / \mathrm{A}\end{array}$ & $\begin{array}{l}37.0-40.0 \% \text { (non-selected BMC) } \\
35.0-38.0 \% \text { (CD34-CXCR4 BMC) }\end{array}$ & $+3^{\star}$ (for both groups) & (28) \\
\hline Traverse (2010) & 40 & STEMI & 6 & $\begin{array}{l}\text { Echocardiography } \\
\text { MRI }\end{array}$ & $48.6 \pm 8.5-57.0 \pm 13.4 \%$ & $49.0 \pm 9.5-55.2 \pm 9.8 \%$ & +6.2 & (29) \\
\hline BONAMI (2010) & 101 & Acute Ml & 3 & $\begin{array}{l}\text { RNA } \\
\text { MRI } \\
\text { Echocardiography } \\
\text { SPECT }\end{array}$ & $37.0 \pm 6.7-41.3 \pm 9.0 \%$ & $35.6 \pm 7.0-38.9 \pm 10.3 \%$ & +3.3 & (30) \\
\hline
\end{tabular}


TABLE 1 | Continued

\begin{tabular}{|c|c|c|c|c|c|c|c|c|}
\hline \multirow[t]{2}{*}{ Study } & \multirow{2}{*}{$\begin{array}{l}\text { Number of } \\
\text { patients }\end{array}$} & \multirow[t]{2}{*}{ Type of patients } & \multirow{2}{*}{$\begin{array}{l}\text { Duration } \\
\text { (months) }\end{array}$} & \multirow[t]{2}{*}{ Imaging modality } & \multicolumn{3}{|c|}{ Changes in left ventricular ejection fraction (LVEF) } & \multirow[t]{2}{*}{ Reference } \\
\hline & & & & & Placebo & Treated & $\%$ Changes in LVEF (treated) & \\
\hline REPAIR-AMla (2010) & 204 & Acute Ml & 24 & $\begin{array}{l}\text { LV angiography } \\
\text { MRI }\end{array}$ & $48.7-43.6 \%$ & $45.4-50.1 \%$ & $+4.7^{\star}$ & (31) \\
\hline FOCUS-HF (2011) & 30 & Ischemic HF & 6 & $\begin{array}{l}\text { Echocardiography } \\
\text { SPECT } \\
\text { LV angiography }\end{array}$ & $40.0 \pm 3.2-40.9 \pm 8.5 \%$ & $37.5 \pm 8.2-42.0 \pm 14.4 \%$ & $+4.5^{\star}$ & (32) \\
\hline HEBE $(2011)^{a}$ & 200 & Acute Ml & 4 & MRI & $42.4 \pm 8.3-46.4 \pm 9.2 \%$ & $43.7 \pm 9.0-47.5 \pm 9.9 \%$ & $+3.8^{*}$ & (33) \\
\hline Late TIME (2011) & 87 & Acute Ml & 6 & $\begin{array}{l}\text { Echocardiography } \\
\text { MRI }\end{array}$ & $45.3 \pm 9.9-48.8 \pm 7.8 \%$ & $48.7 \pm 12.0-49.2 \pm 13.0 \%$ & +0.5 & (34) \\
\hline TOPCARE-AMla (2011) & 55 & Acute Ml & 60 & MRI & N/A & $46.0 \pm 10.0-57.0 \pm 10.0 \%$ & $+11^{*}$ & (35) \\
\hline TIME (2012) & 120 & Acute Ml & 6 & $\begin{array}{l}\text { MRI } \\
\text { Echocardiography }\end{array}$ & $44.5 \pm 10.8-47.8 \pm 13.6 \%$ & $45.1 \pm 10.6-48.3 \pm 13.3 \%$ & +3.2 & (36) \\
\hline Antonitsis (2012) & 9 & $\begin{array}{l}\text { Ischemic } \\
\text { cardiomyopathy }\end{array}$ & 12 & $\begin{array}{l}\text { Echocardiography } \\
\text { SPECT }\end{array}$ & $\mathrm{N} / \mathrm{A}$ & $31.3 \pm 6.5-52.5 \pm 8.9 \%$ & $+21.2^{\star}$ & (37) \\
\hline FOCUS-CCTRN (2012) & 92 & Chronic HF & 6 & SPECT & $32.3-31.0 \%$ & $34.7-36.1 \%$ & +1.4 & (38) \\
\hline SWISS AMI (2013) & 200 & STEMI & 4 & MRI & $40.0 \pm 9.9-38.7 \pm 17.3 \%$ & $\begin{array}{c}36.5 \pm 9.9-37.9 \pm 10.3 \% \text { (early } \\
\text { injection }-5-7 \text { days post-MI) } \\
36.3 \pm 8.2-37.4 \pm 9.7 \% \text { (late } \\
\text { injection }-3-4 \text { weeks post-MI) }\end{array}$ & $\begin{array}{c}+1.4 \text { (early injection }-5-7 \text { days } \\
\text { post-MI) } \\
+1.1 \text { (late injection }-3-4 \text { weeks } \\
\text { post-MI) }\end{array}$ & (39) \\
\hline
\end{tabular}

N/A, not applicable (Placebo group was not included in trial); HF, heart failure; MI, myocardial infarction; LV, left ventricular; STEMI, ST-elevated myocardial infarction; PET, positron emission tomography;

MRI, magnetic resonance imaging; SPECT, single-photon-emission computed tomography; RNA, radionuclide angiography.

${ }^{a}$ Follow-up studies.

*Significant improvement in LVEF $(p<0.05)$. 
and found no trans-differentiation of HSCs into cardiomyocytes (12). Moreover, Balsam and colleagues showed that when $\mathrm{GFP}^{+} \mathrm{Lin}^{-} \mathrm{c}-\mathrm{kit}^{+} \mathrm{HSC}$ were injected into infarcted mouse hearts, abundant $\mathrm{GFP}^{+}$cells were detected in the myocardium at 10 days, with few cells detectable at 30 days (13). It was found that the $\mathrm{GFP}^{+}$cells did not express cardiac tissue-specific markers, but expressed the hematopoietic marker CD45 and myeloid marker Gr-1, representing mature hematopoietic fates.

More recently, van Berlo et al. (40) generated c-kit ${ }^{\text {cre }}$-IRESeGFP knocked-in mice to revisit the fate of c-kit ${ }^{+}$cells in development and following injury (40). They found that most eGFP-c-kit ${ }^{+}$cells were mainly non-myocytes in the developing and injured adult heart. Indeed, $\mathrm{c}^{-\mathrm{kit}^{+}}$cells largely adopted an endothelial lineage phenotype in the developing or infarcted heart, and rarely became cardiomyocytes $(41,42)$. While these models set out to tag all c-kit ${ }^{+}$cells in the organism, questions were raised over the fidelity of the model and reporter gene to successfully recombine the endogenous, resident cardiac stem, and progenitor cells, which also express c-kit (43).

\section{BONE MARROW-DERIVED MESENCHYMAL STEM CELLS}

Mesenchymal stem cells, or also known as mesenchymal stromal cells (MSCs), are a subset of bone marrow-derived stem cells that have plastic adherence characteristics, express CD105, CD73, and CD90 but not CD34, CD45, CD14 or CD11b, CD79 $\alpha$ or CD19, and HLA-DR, and possess the ability to form adipocytes, chondrocytes, and osteoblasts in vitro (44). As MSCs express low MHC Class I and are lacking MHC Class II (45), the phenotype confers the capability of evading host immune responses and hence enables the cells for allogeneic transplantation (45). Several in vivo studies showed improvements in myocardial function despite low rates of MSC engraftment and differentiation $(46,47)$. Although trans-differentiation of MSCs into cardiomyocytes was achievable by using demethylating chemicals $(48,49)$ or by coculturing with rodent myocytes in vitro $(50,51)$, the event in vivo had been reportedly low (52). Furthermore, electrophysiological analysis revealed that differentiated myocytes did not possess similar electrical properties to a functional cardiomyocyte (53). Hence, the main regenerative function of MSCs was largely confined to its secretome, which contained a plethora of factors with cardioprotective effects, or stimulants that activate endogenous repair mechanisms including the resident cardiac stem and progenitor cells $(54,55)$.

Many trials had been conducted to examine the therapeutic efficacy of MSCs in regenerating damaged human hearts at different severities, either with autologous or allogeneic cell sources (Table 2). In POSEIDON, transendocardial-administered allogeneic BM-MSCs attenuated the progressive heart remodeling, reduced the scar mass, and improved the early enhancement defect and sphericity index in ischemic cardiomyopathic patients, and the effects were greater with a lower cell dose (20 million), as compared to a higher dose (200 million) (56). The injected allogeneic MSCs did not trigger immune responses in recipients, and the observed benefits were mostly similar to autologous MSCs (56). However, both allogenic and autologous MSC-treated groups did not show significant improvements in ejection fraction. In contrast, the phase 2, placebo-controlled randomized MSC-HF trial reported encouraging results, which demonstrated that HF patients who received a high number of intramyocardially delivered autologous MSCs showed greater functional improvements in the ischemic heart after 12 months (57). They also suggested a possible correlation between cell dose and disease severity. Through a longer, 2-year follow-up, the phase 1 pilot study MESAMI revealed similar benefits from intramyocardial MSC injection in patients with chronic ischemic cardiomyopathy, albeit with a smaller sample size of $10(58)$.

\section{ENDOGENOUSLY DERIVED RESIDENT CARDIAC STEM AND PROGENITOR CELLS}

\section{c-kit ${ }^{+}$Cardiac Stem Cells (CSCs)}

The first reported primitive CSCs present in the heart were identified and isolated based on the expression of stem cell factor receptor CD117 or c-kit. c-kit ${ }^{+}$CSCs are also positive for Sca-1 $\left(60 \pm 10 \%\right.$ of c-kit ${ }^{+}$eCSCs are also Sca- $\left.1^{+}\right)$, MDR-1 (ABCG2), and other markers identified on adult cardiac stem and progenitor cell populations, such as CD105, CD166, PDGFra, and CD90. c-kit ${ }^{+}$CSCs do not express CD34, CD31, CD45, or tryptase, distinguishing them from $\mathrm{c}$-kit ${ }^{+}$endothelial (progenitor) cells and mast cells $(64,65)$. CSCs are multipotent, self-renewing, and capable of forming cardiomyocytes, smooth muscle cells, and endothelial cells $(64,65)$, and their turnover was coupled with cellular homeostasis in the heart (66). In the adult heart, most of the CSCs were found to reside in the atrium and the ventricular apex, albeit at a very low density ( 1 cell per every 10,000 myocytes) (64). Owing to the scarcity of the CSCs, an optimized protocol had been developed to isolate and characterize these cells (67). CSCs can be propagated over long-term culture and maintained in an undifferentiated, self-renewing, stable state, without showing evidence of senescent growth arrest or abnormal karyotype (68). Preclinical studies showed that these $\mathrm{c}-\mathrm{kit}^{+} \mathrm{CSC}$ regenerated both the hearts of rats $(64,69)$ and mice $(65,70)$ post-infarction via the formation of new myocytes and vasculature, and protected the preexisting cardiomyocytes from apoptosis through the secretion of IGF-1 $(71,72)$. The significance of CSCs was further highlighted in an elegant experiment which employed an animal model by which the proliferating cells in the damaged heart were totally ablated using 5-flurouracil, which lead to a blunted the recovery of the injured heart (69). However, the recovery was reversed, both anatomically and functionally, through the administration of c-kit ${ }^{+}$clonogenic CSCs, suggesting their indispensable role in restoring and initiating myocardial repair and regeneration in response to injury.

c-kit ${ }^{+}$CSCs have been tested in human trials (Table 3). The phase 1 stem cell infusion in patients with ischemic cardiomyopathy (SCIPIO) trial showed that intracoronary administration of $\mathrm{c}-\mathrm{kit}^{+}$ CSCs (1 million) increased the left ventricular ejection fraction (LVEF) by 7.6 and $13.7 \%$ with decreased infarct size of 6.9 and 
TABLE 2 | Clinical trials using bone marrow-derived mesenchymal stem cells.

\begin{tabular}{|c|c|c|c|c|c|c|c|c|}
\hline \multirow[t]{2}{*}{ Study } & \multirow{2}{*}{$\begin{array}{l}\text { Number of } \\
\text { patients }\end{array}$} & \multirow[t]{2}{*}{ Type of patients } & \multirow{2}{*}{$\begin{array}{l}\text { Duration } \\
\text { (months) }\end{array}$} & \multirow{2}{*}{$\begin{array}{l}\text { Imaging } \\
\text { modality }\end{array}$} & \multicolumn{3}{|c|}{ Changes in left ventricular ejection fraction (LVEF) } & \multirow[t]{2}{*}{ Reference } \\
\hline & & & & & Placebo & Treated & $\begin{array}{l}\% \text { Changes in } \\
\text { LVEF (treated) }\end{array}$ & \\
\hline Chen (2004) & 69 & Acute Ml & 6 & $\begin{array}{l}\text { Echocardiography } \\
\text { PET }\end{array}$ & $\begin{array}{l}48.0 \pm 10.0- \\
54.0 \pm 5.0 \%\end{array}$ & $49.0 \pm 9.0-67.0 \pm 3.0 \%$ & $+18^{*}$ & (59) \\
\hline Hare (2009) & 53 & Acute Ml & 6 & $\begin{array}{l}\text { Echocardiography } \\
\text { MRI }\end{array}$ & $48.7-56.1 \%$ & $50.4-56.9 \%$ & +6.5 & (60) \\
\hline POSEIDON (2012) & 30 & $\begin{array}{l}\text { Ischemic } \\
\text { cardiomyopathy }\end{array}$ & 13 & $\begin{array}{l}\text { Echocardiography } \\
\text { CT }\end{array}$ & $\mathrm{N} / \mathrm{A}$ & $\begin{array}{l}27.85-29.5 \% \text { (allogeneic) } \\
26.23-28.53 \% \text { (autologous) }\end{array}$ & $\begin{array}{l}+1.65 \text { (allogeneic) } \\
+2.3 \text { (autologous) }\end{array}$ & (56) \\
\hline PROMETHEUS (2014) & 6 & $\begin{array}{l}\text { Ischemic left ventricular } \\
\text { dysfunction secondary } \\
\text { to } \mathrm{Ml}\end{array}$ & 18 & MRI & N/A & $41.2 \pm 4.9-51.3 \pm 5.4 .0 \%$ & $+10.1^{\star}$ & (61) \\
\hline SEED-MSC (2014) & 80 & Acute Ml & 6 & $\begin{array}{l}\text { Echocardiography } \\
\text { SPECT }\end{array}$ & $\begin{array}{l}49 \pm 11.7- \\
55 \pm 11.8 \%\end{array}$ & $52.3 \pm 9.3-53.9 \pm 10.2 \%$ & $+1.6^{\star}$ & (62) \\
\hline MSC-HF (2015) & 55 & Ischemic HF & 6 & $\begin{array}{l}\text { Echocardiography } \\
\text { MRI } \\
\text { CT }\end{array}$ & $25.1-23.8 \%$ & $28.2-33.2 \%$ & $+5^{*}$ & (57) \\
\hline MESAMI (2016) & 10 & $\begin{array}{l}\text { Ischemic } \\
\text { cardiomyopathy }\end{array}$ & 12 & $\begin{array}{l}\text { Echocardiography } \\
\text { SPECT }\end{array}$ & $\mathrm{N} / \mathrm{A}$ & $29.4 \pm 2.0-35.7 \pm 2.5 \%$ & $+6.3^{*}$ & (58) \\
\hline
\end{tabular}

N/A, not applicable (Placebo group was not included in trial); HF, heart failure; MI, myocardial Infarction; LV, left ventricular; PET, positron emission tomography; MRI, magnetic resonance imaging; SPECT, single-photon-emission computed tomography; CT, cardiac tomography; MSC, mesenchymal stromal cell.

${ }^{*}$ Significant improvement in $\operatorname{LVEF}(\mathrm{p}<0.05)$.

TABLE 3 | Clinical trials using cardiac stem cells.

\begin{tabular}{|c|c|c|c|c|c|c|c|c|}
\hline \multirow[t]{2}{*}{ Study } & \multirow[t]{2}{*}{$\begin{array}{l}\text { Number of } \\
\text { patients }\end{array}$} & \multirow[t]{2}{*}{$\begin{array}{l}\text { Type of } \\
\text { patients }\end{array}$} & \multirow[t]{2}{*}{$\begin{array}{l}\text { Duration } \\
\text { (months) }\end{array}$} & \multirow[t]{2}{*}{$\begin{array}{l}\text { Imaging } \\
\text { modality }\end{array}$} & \multicolumn{3}{|c|}{$\begin{array}{l}\text { Changes in left ventricular ejection } \\
\text { fraction (LVEF) }\end{array}$} & \multirow[t]{2}{*}{ Reference } \\
\hline & & & & & Placebo & Treated & $\begin{array}{l}\% \text { Changes in } \\
\text { LVEF (treated) }\end{array}$ & \\
\hline SCIPIO (2011) & 23 & $\mathrm{HF}$ & 4 & $\begin{array}{l}\text { Echocardiography } \\
\text { MRI }\end{array}$ & $30.1 \pm 2.4-30.2 \pm 2.5 \%$ & $30.3 \pm 1.9-38.5 \pm 2.8 \%$ & $+8.2^{*}$ & (73) \\
\hline SCIPIOa (2012) & 33 & $\mathrm{HF}$ & 4 and 12 & $\begin{array}{l}\text { Echocardiography } \\
\text { MRI }\end{array}$ & $\mathrm{N} / \mathrm{A}$ & $\begin{array}{c}27.5 \pm 1.6-35.1 \pm 2.4 \% \text { (4th } \\
\text { month) and } 41.2 \pm 4.5 \% \text { (12th } \\
\text { month) }\end{array}$ & $\begin{array}{l}+7.6^{*}(4 \text { th month }) \\
+13.7(12 \text { th } \\
\text { month })\end{array}$ & (74) \\
\hline $\begin{array}{l}\text { CADUCEUS } \\
\text { (2012) }\end{array}$ & 25 & $\mathrm{Ml}$ & 6 & $\mathrm{MRI}$ & $39-44.8 \%$ & $38-43.4 \%$ & +5.4 & (76) \\
\hline $\begin{array}{l}\text { CADUCEUS } \\
(2014)\end{array}$ & 25 & Ml & 12 & MRI & $42.5 \pm 11.1-48.2 \pm 11.4 \%$ & $42.4 \pm 8.9-48.2 \pm 10.3 \%$ & +5.4 & (77) \\
\hline
\end{tabular}

N/A, not applicable (Placebo group was not included in trial); HF, heart failure; MI, myocardial infarction; LV, left ventricular; MRI, magnetic resonance imaging.

aFollow-up studies.

*Significant improvement in $\operatorname{LEF}(p<0.05)$.

$7.8 \mathrm{~g}$ after 4 and 12 months, respectively $(73,74)$. A study was also performed to address the safety of intracoronary infusion of 20 million c-kit ${ }^{+}$CSCs into swine hearts (75). The results showed neither renal and liver damage nor further myocardial injury due to microembolism. Nonetheless, the cell retention in the myocardium remained low despite the high number of infused cells.

\section{Cardiospheres and Cardiosphere-Derived Cells (CDCs)}

Cardiospheres are $20-150 \mu \mathrm{m}$ cellular spheres, which are generated from the explant outgrowth cells of heart biopsies $(65,78)$. These cardiospheres supposedly consist of CSCs that reside in the core and cardiac lineage committed cells (e.g., myofibroblasts) and differentiated cells (vascular smooth muscle cells, endothelial 
cells), which comprise the outer layer of the spheres (65). The three-dimensional microenvironment of cardiospheres had been shown to protect the CSCs from oxidative stress as well as maintain their stemness and function (79). When these cardiospheres were expanded on fibronectin, the CDCs became highly proliferative in the monolayer and were clonogenic and multipotent, in vitro (80). This enables fast and efficient expansion of the CDCs for heart therapy, with retained regenerative potential $(78,81,82)$. The therapeutic effects of CDCs had also been demonstrated in in vivo studies, ranging from small-to-large animal models $(81,83,84)$ and in human trials $(76,85)$. CDCs showed potential in reducing infarct size, improving LVEF and cardiac hemodynamics in infarcted animal models $(81,83)$, which could be maintained for up to 16 weeks (82). The positive observation in in vivo studies led to the initiation of a randomized phase 1 clinical trial, known as the cardiosphere-derived autologous stem cells to reverse ventricular dysfunction study or the CADUCEUS trial (76). The trial showed significant reductions in scar mass ( $8.4 \mathrm{~g}$ in the first 6 months and $12.9 \mathrm{~g}$ after a year) but no differences in the LVEF.

\section{RELATIONSHIP BETWEEN BONE MARROW-DERIVED CELLS AND RESIDENT CSCs}

Cardiospheres and CDCs represent a mixed cell population, which employs an assortment of heterogeneous cells and this heterogeneity sparks the idea of employing synergistic effects between various cells to aid CSCs to perform better for cardiac regeneration.

Mononuclear bone marrow cells had been shown to benefit the injured myocardium after their administration, but the effect was then concluded as not sustainable. Paracrine signaling is a generally accepted explanation for the mechanism of repair, regeneration, and modest improvement in cardiac function. Loffredo et al. (86) conducted a sophisticated experiment using bitransgenic MerCreMer ZEG mice to study the degree of new myocyte formation after induced injury in the heart, following BMDC transplantation (86). In this model, all cardiomyocytes were permanently shifted to express GFP from $\beta$-galatosidase ( $\beta$-gal) by a pulse treatment of $4-\mathrm{OH}$ tamoxifen, and all new myocytes were identified as non-GFP expressing $\beta$-gal-positive cells. The study revealed that the number of new myocytes was greater in subjects treated with c-kit ${ }^{+}$bone marrow MNCs. This coincided with increased resident GATA4 ${ }^{+} \mathrm{Nkx} 2.5^{+}$cardiac progenitors, which was not observed when the subjects were given bone marrow MSCs. Moreover, Hatzistergos et al. (54) used GFPtransduced MSCs and when transendocardially injected them into the infarcted heart of the Yorkshire swine and showed increased $\mathrm{GFP}^{-}$c-kit cells by 2 - and 15 -fold in the infarcted and border regions, respectively (54). These cells coexpressed MDR-1 and GATA4, suggesting that they were of endogenous CSC origin. These findings were consistent with the in vitro data which showed that greater $\mathrm{c}-\mathrm{kit}^{+} \mathrm{CSC}$ s were mobilized from heart explant cultures in the presence of MSC feeder layers (87). In addition to the activation of the endogenous pool of CSCs, MSCs prompted cardiomyocyte proliferation, which correlated with an increased number of cardiomyocytes expressing serine 10 phosphorylated histone H3, a mitotic marker indicative of cell cycling (54). The regenerative capability of MSCs was further confirmed with a study by Suzuki et al. (88), which discovered the ability of MSCs in mobilizing CD133 and c-kit ${ }^{+}$bone marrow cells as well as stimulating myocyte proliferation in chronic hibernating myocardium (88). Indeed, the administration of MSCs was found to drive the

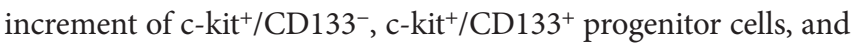
$\mathrm{Ki} 67^{+}$and phospho-histone $\mathrm{H} 3^{+}$cardiomyocytes.

The synergistic effects between MSCs and heart-derived, resident c-kit ${ }^{+} \mathrm{CSC}$ s were further confirmed in two studies where cotransplantation of both cell types showed greater amelioration in improving cardiac performance and scar size post-infarction $(89,90)$. Both transepicardial and transendocardial administrations of either xenogenic or autologous MSCs showed greater scar reductions and global heart function restorations as compared to single-cell administration in swine model, which illustrates the interaction between MSCs and CSCs in enhancing the regeneration of the heart post-infarction.

\section{CSCs RELATIONSHIP WITH OTHER CELLS}

\section{Telocytes}

Telocytes, which were first described in 2009 as interstitial Cajallike cells, are peculiar stromal cells that were recently found to reside in the interstitium in all heart layers (91-93). These cells express vimentin and CD34, with several reports that showed coexpressions with c-kit or PDGFR- $\beta$ markers (94). Of note, the unique phenotype that distinguishes telocytes from other interstitial cells is the distinct and very fine cellular prolongation called telopodes. The average length of these telopodes could extend from a few ten to hundred microns. Transmission electron microscopic analysis showed that most of the telocytes intermingled with adjacent cardiomyocytes and precursors of telopodes forming an organized myocyte cluster that was integrated in the myocardium (95). Furthermore, changes in number of telocytes have also found to be associated with severe alterations in heart matric architecture (96), and transplantation of telocytes into injured rat hearts had also shown improved functions (97). Although there is no direct evidence that demonstrates how telocytes functionally influence CSC activity in vivo, the distribution and organization of these telocytes in the myocardial interstitium, however, support the notion that they may be an important "nurse" cell in the CSC niche that governs endogenous precursors and immature cardiac myocytes in heart development and regeneration (98).

\section{Epicardial-Derived Cells (EPDCs)}

The epicardium consists of a unique population of cells that originated from the proepicardial organ expressing WT1, Tbx18, and retinaldehyde dehydrogenase 2 . These cells enveloped the developing heart and formed distinct layers of epicardium and subepicardial mesenchyme, which promoted cardiomyocyte proliferation, triggered myocardial expansion to generate thick myocardium during heart development $(99,100)$. EPDCs contributed to the majority of non-myocyte support cells, such as 
cardiac fibroblasts and smooth muscle cells and their invasion to the myocardium and endocardium was accomplished via the epithelial-mesenchymal transition (101). A study conducted by Winter et al. (102) showed that EPDCs facilitated cardiomyocyte progenitor cell (CMPC) proliferation under hypoxic conditions $\left(1 \% \mathrm{O}_{2}\right)$ in coculture, albeit with decreased cell motility (102). Coculture of both EPDCs and CMPCs produced increased angiogenic factors, such as VEGF and PDGF-BB. In vivo, an MRI study showed an improvement in ejection fraction and a significant decrease in end systolic and diastolic volumes when both cells were administered. Significantly higher endothelial densities at the border and infarcted zones were also observed, with preserved ventricular wall thickness. However, in vivo results showed that there were little to no cell engraftment or differentiation in the infarcted heart after EPDC/CMPC administration. This suggests that a paracrine interaction may be the main reason for the improved heart function, and the CMPCs were enhanced through the secretion of growth factors by EPDCs (102).

\section{Circulatory Angiogenic Cells (CACs)}

Surviving hostile environments primarily requires the establishment of perfusion and revascularization of the infarct regions. Hence, the vascular network within the injected region is key to cell survival. CACs, or early outgrowth endothelial progenitor cells, were considered blood-derived cells that play a role in both vasculogenesis and angiogenesis in promoting myocardial repair, mainly through paracrine interaction (103). A study by Latham et al. (103) demonstrated that conditioned medium from CAC-CSC cocultures showed greater capacity in mobilizing CACs and inducing tubule formation in HUVECs in vitro, which was attributed to the upregulation of angiogenic factors, such as angiogenin, SDF-1 $\alpha$, and VEGF. Echocardiography showed significant restoration of the LVEF and reduced scar formation in infarcted hearts of NOD/severe combined immunodeficient (SCID) mice following coadministration of CACs and CSCs (103). These improvements were also coupled with successful but modest smooth muscle cell, endothelial cell, and cardiomyocyte differentiation.

\section{Saphenous Vein-Derived Pericytes (SVPs)}

Pericytes (also known as Rouget cells, mural cells, or perivascular mesenchymal precursor cells) are mesodermal cells that surround the endothelial lining in the microvasculature. These cells were highly proliferative and express neural/glial antigen 2, Sox-2, PDGFr $\beta$, CD34, and several mesenchymal markers such as CD105, CD90, and CD44. Various studies have suggested that the transplantation of SVPs into ischemic limb was previously found to restore the regional circulatory network via new vessel formation in immunodeficient mice (104). Moreover, fibrotic scar, cardiomyocyte death, and vascular permeability were found to be reduced in infarcted mice myocardium that was treated with SVP, via microRNA-132-mediated angiogenesis (105). The relationship of the SVP with the endogenous CSC was first described by Avolio et al. (106). However, unlike the bone marrow-derived MSCs, the in vivo study suggested no additional benefits in restoring the ventricular function and hemodynamics when CSCs were intramyocardially cotransplanted with SVP into the infarcted heart of SCID/Beige-immunodeficient mice. Although mice that received both cells showed greater reductions in scar size, the differences were not statistically significant when compared to treatment with CSCs or SVP cells only (106).

\section{CARDIAC CELL THERAPY IN CLINICAL TRIALS}

Bone marrow-derived stem cells remain the most common, first-generation cell candidate used in clinical transplantation. A striking report by Nowbar et al. (107), who conducted a weighted regression and meta-analysis to study 49 trial reports using autologous bone marrow stem cells and outlined the discrepancies between these trials, concluded that only $10 \%$ of the human studies were performed without errors with none showing benefits from BMNCs (107). In contrast, Fisher et al. (108) performed a systemic review that excluded all the non-randomized trials, of which contributed to the majority of discrepancies outlined in Nowbar's report, and suggested that autologous bone marrow stem cell treatment can improve HF patients' quality of life and exercise capacity (108). Their findings are in line with a recent meta-analysis which included 48 randomized-controlled trials by Afzal et al. (109) and also agreed that bone marrow-derived cells (both BMNCs and MSCs) improved heart function in ischemic heart disease patients (109). Nonetheless, it is widely accepted that the therapeutic benefits from bone marrow-derived cells are mainly attributed to a paracrine mechanism that activates endogenous healing. Reconstituting injured myocardium with cardiomyocytes may require second-generation cardiogenic cells, the more defined, homogeneous cardiac-derived stem/ progenitor cells or pluripotent stem cells, some of which have been used for clinical trials $(73,74,76,77,110)$ (Figure 2). Careful selection of cell candidates, mode of delivery, employment of cell engraftment and enhancement strategies, in-depth investigation of mechanisms of efficacy, and clinically meaningful endpoints in future experimental studies can help to advance cardiac cell therapy (111).

\section{FUTURE DIRECTIONS: EMERGING, STATE-OF-THE-ART APPLICATIONS IN HEART TISSUE ENGINEERING}

Although several stem cells have been proposed to regenerate the heart, there is no consensus on the best cell type to be used in cellular therapy and the search for establishing a gold standard is still ongoing. Given the complexity of the heart, and the emptiness of the infarcted area, the regeneration process will require multiple coordinations from different therapeutic cells with synergistic functions, together with an established extracellular matrix scaffold. Some in vivo studies have investigated these approaches, but it has not been widely explored. It is important to realize that most experiments are conducted in two-dimensional culture systems and little is known about the survival and performance of these interactions in the three-dimensional structure. These questions lead back to the fundamental investigation of determining the optimal cell types for the engineering of tissue 


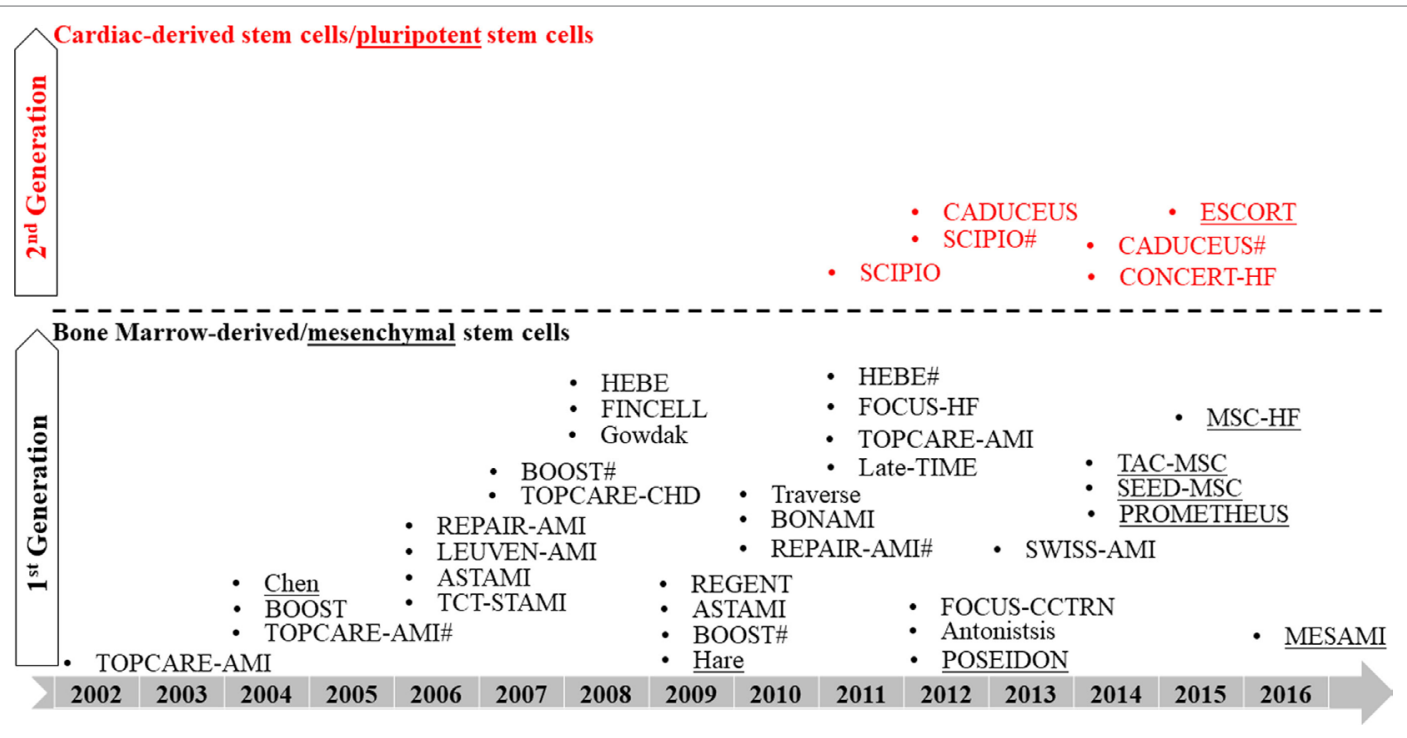

FIGURE 2 | Roadmap of clinical trials using first- and second-generation cells. " indicates follow-up study.

constructs, and their functional behaviors in three-dimensional cultures. Ott et al. (112) demonstrated a new concept of producing bio-engineered hearts by using the natural hearts from rats (112) by decellularizing the heart scaffold using detergents, then re-cellularizing through introducing neonatal cardiac cells and endothelial cells (112).

With the invention of induced-pluripotent stem (IPS) cells, the mass generation of human cardiomyocytes is no longer difficult. The challenging aspect, however, is reintroducing the cells into the construct, finding the means of ensuring their long-term survival and identifying the factors that drive their maturation. Lei Yang's laboratory generated cardiovascular progenitors from IPS cells and attempted to reintroduce these cells into the decellularized mouse heart scaffold. The group demonstrated ex vivo proliferation, migration, and differentiation in the threedimensional construct, but failed to regrow the myocardium to acquire sufficient strength for pumping fluid like the native heart (113). Another similar study by Guyette et al. (114) repopulated decellularized human hearts with cardiomyocytes derived from IPS cells. This study showed that the cardiomyocytes successfully engrafted onto the cardiac scaffolds and showed electrical conductivity and thus set the ground for the translational value of using acellular human heart matrix for complete myocardial regeneration in the future (114). A complex three-dimensional construct is an extremely promising approach for heart

\section{REFERENCES}

1. World Health Organisation. Global Status Report on Noncommunicable Disease. WHO Press (2014).

2. Thygesen K, Alpert JS, White HD. Universal definition of myocardial infarction. Circulation (2007) 116:2634-53. doi:10.1161/CIRCULATIONAHA. 107.187397

3. Minicucci MF, Azevedo PS, Polegato BF, Paiva SAR, Zornoff LAM. Heart failure after myocardial infarction: clinical implications and treatment. Clin Cardiol (2011) 34(7):410-4. doi:10.1002/clc.20922 regeneration. However, the research is still in its infancy, and more studies are required before this technique can be translated into clinical applications.

\section{AUTHOR CONTRIBUTIONS}

JT and GE-H contributed to the conception and design of the review. YL, WN, and JT prepared, drafted, and wrote the manuscript. JT and GE-H wrote, critically revised, proofread, and approved the manuscript.

\section{ACKNOWLEDGMENTS}

YL and WN thank Malaysian Civil Service Department (JPA) for sponsoring their studentship under Yang di-Pertuan Agong scholarship.

\section{FUNDING}

JT is a recipient of Universiti Sains Malaysia Research University Grant (Individual: 1001/CIPPT/811226) and Science Fund from Malaysian Ministry of Science Technology and Innovation (305/ CIPPT/613231). GE-H is a recipient of BHF PG 14/11/30657 and grant from BHF Centre of Regenerative Medicine.

4. Sutton MGSJ, Sharpe N. Left ventricular remodeling after myocardial infarction pathophysiology and therapy. Circulation (2000) 101:2981-8. doi:10.1161/01. CIR.101.25.2981

5. Deb A, Wang S, Skelding KA, Miller D, Simper D, Caplice NM. Bone marrow-derived cardiomyocytes are present in adult human heart: a study of gender-mismatched bone marrow transplantation patients. Circulation (2003) 107(9):1247-9. doi:10.1161/01.CIR.0000061910.39145.F0

6. Laflamme MA, Myerson D, Saffitz JE, Murry CE. Evidence for cardiomyocyte repopulation by extracardiac progenitors in transplanted human hearts. Circ Res (2002) 90(6):634-40. doi:10.1161/01.RES.0000014822.62629.EB 
7. Quaini F, Urbanek K, Beltrami AP, Finato N, Beltrami CA, Nadal-Ginard B, et al. Chimerism of the transplanted heart. N Engl J Med (2002) 346(1):5-15. doi:10.1056/NEJMoa012081

8. Behfar A, Crespo-Diaz R, Terzic A, Gersh BJ. Cell therapy for cardiac repair-lessons from clinical trials. Nat Rev Cardiol (2014) 11(4):232-46. doi:10.1038/nrcardio.2014.9

9. Fujii H, Tomita S, Nakatani T, Fukuhara S, Hanatani A, Ohtsu Y, et al. A novel application of myocardial contrast echocardiography to evaluate angiogenesis by autologous bone marrow cell transplantation in chronic ischemic pig model. J Am Coll Cardiol (2004) 43(7):1299-305. doi:10.1016/j.jacc.2003.09.061

10. Asahara T, Masuda H, Takahashi T, Kalka C, Pastore C, Silver M, et al. Bone marrow origin of endothelial progenitor cells responsible for postnatal vasculogenesis in physiological and pathological neovascularization. Circ Res (1999) 85(3):221-8. doi:10.1161/01.RES.85.3.221

11. Orlic D, Kajstura J, Chimenti S, Jakoniuk I, Anderson SM, Li B, et al. Bone marrow cells regenerate infarcted myocardium. Nature (2001) 410(6829): 701-5. doi:10.1038/35070587

12. Murry CE, Soonpaa MH, Reinecke H, Nakajima H, Nakajima HO, Rubart M, et al. Haematopoietic stem cells do not transdifferentiate into cardiac myocytes in myocardial infarcts. Nature (2004) 428(6983):664-8. doi:10.1038/ nature 02446

13. Balsam LB, Wagers AJ, Christensen JL, Kofidis T, Weissman IL, Robbins RC. Haematopoietic stem cells adopt mature haematopoietic fates in ischaemic myocardium. Nature (2004) 428(6983):668-73. doi:10.1038/nature02460

14. Assmus B, Schächinger V, Teupe C, Britten $M$, Lehmann R, Döbert N, et al. Transplantation of progenitor cells and regeneration enhancement in acute myocardial infarction (TOPCARE-AMI). Circulation (2002) 206:3009-17. doi:10.1161/01.CIR.0000043246.74879.CD

15. Schachinger V, Assmus B, Britten MB, Honold J, Lehmann R, Teupe C, et al. Transplantation of progenitor cells and regeneration enhancement in acute myocardial infarction: final one-year results of the TOPCARE-AMI trial. J Am Coll Cardiol (2004) 44(8):1690-9. doi:10.1016/j.jacc.2004.08.014

16. Wollert KC, Meyer GP, Lotz J, Ringes-Lichtenberg S, Lippolt P, Breidenbach C, et al. Intracoronary autologous bone-marrow cell transfer after myocardial infarction: the BOOST randomised controlled clinical trial. Lancet (2004) 364:141-8. doi:10.1016/S0140-6736(04)16626-9

17. Meyer GP, Wollert KC, LotzJ, Steffens J, Lippolt P, Fichtner S, et al. Intracoronary bone marrow cell transfer after myocardial infarction. Circulation (2006) 113:1287-94. doi:10.1161/CIRCULATIONAHA.105.575118

18. Schächinger V, Erbs S, Elsässer A, Haberbosch W, Hambrecht R, Hölschermann $\mathrm{H}$, et al. Intracoronary bone marrow-derived progenitor cells in acute myocardial infarction. N Engl J Med (2006) 355:1210-21. doi:10.1056/ NEJMoa060186

19. Janssens S, Dubois C, Bogaert J, Theunissen K, Deroose C, Desmet W, et al. Autologous bone marrow-derived stem-cell transfer in patients with ST-segment elevation myocardial infarction: double-blind, randomised controlled trial. Lancet (2006) 367:113-21. doi:10.1016/S0140-6736(05)67861-0

20. Lunde K, Solheim S, Aakhus S, Arnesen H, Abdelnoor M, Egeland T, et al. Intracoronary injection of mononuclear bone marrow cells in acute myocardial infarction. N Engl J Med (2006) 355(12):1199-209. doi:10.1056/ NEJMoa055706

21. Ge J, Li Y, Qian J, Shi J, Wang Q, Niu Y, et al. Efficacy of emergent transcatheter transplantation of stem cells for treatment of acute myocardial infarction (TCT-STAMI). Heart (2006) 92:1764-7. doi:10.1136/hrt.2005. 085431

22. Assmus B, Fischer-Rasokat U, Honold J, Seeger FH, Fichtlscherer S, Tonn T, et al. Transcoronary transplantation of functionally competent BMCS is associated with a decrease in natriuretic peptide serum levels and improved survival of patients with chronic postinfarction heart failure. Circ Res (2007) 100:1234-41. doi:10.1161/01.RES.0000264508.47717.6b

23. Gowdak LH, Schettert IT, Baptista E, Lopes NL, Rochitte CE, Vieira ML, et al. Intramyocardial injection of autologous bone marrow cells as an adjunctive therapy to incomplete myocardial revascularization - safety issues. Clinics (2008) 63(2):207-14. doi:10.1590/S1807-59322008000200009

24. Huikuri HV, Kervinen K, Niemela M, Ylitalo K, Säily M, Koistinen P, et al. Effects of intracoronary injection of mononuclear bone marrow cells on left ventricular function, arrhythmia risk profile, and restenosis after thrombolytic therapy of acute myocardial infarction. Eur Heart J (2008) 29(22):2723-32. doi:10.1093/eurheartj/ehn436
25. Hirsch A, Nijveldt R, van der Vleuten PA, Tio RA, van der Giessen WJ, Marques KMJ, et al. Intracoronary infusion of autologous mononuclear bone marrow cells in patients with acute myocardial infarction treated with primary PCI: pilot study of the multicenter HEBE trial. Catheter Cardiovasc Interv (2008) 71:273-81. doi:10.1002/ccd.21337

26. Meyer GP, Wollert KC, Lotz J, Pirr J, Rager U, Lippolt P, et al. Intracoronary bone marrow cell transfer after myocardial infarction: 5-year follow-up from the randomized-controlled BOOST trial. Eur Heart J (2009) 30(24):2978-84. doi:10.1093/eurheartj/ehp374

27. Beitnes JO, Hopp E, Lunde K, Solheim S, Arnesen H, Brinchmann JE, et al. Long-term results after intracoronary injection of autologous mononuclear bone marrow cells in acute myocardial infarction: the ASTAMI randomised, controlled study. Heart (2009) 95:1983-9. doi:10.1136/hrt.2009.178913

28. Tendera M, Wojakowski W, Ruzyłło W, Chojnowska L, Kepka C, Tracz W, et al. Intracoronary infusion of bone marrow-derived selected $\mathrm{CD} 34^{+} \mathrm{CXCR} 4^{+}$ cells and non-selected mononuclear cells in patients with acute STEMI and reduced left ventricular ejection fraction: results of randomized, multicentre myocardial regeneration by intracoronary infusion of selected population of stem cells in acute myocardial infarction (REGENT) trial. Eur Heart J (2009) 30:1313-21. doi:10.1093/eurheartj/ehp073

29. Traverse JH, McKenna DH, Harvey K, Jorgenso BC, Olson RE, Bostrom N, et al. Results of a phase 1, randomized, double-blind, placebo-controlled trial of bone marrow mononuclear stem cell administration in patients following ST-elevation myocardial infarction. Am Heart J (2010) 160(3):428-34. doi:10.1016/j.ahj.2010.06.009

30. Roncalli J, Mouquet F, Piot C, Trochu J-N, Corvoisier PL, Neuder Y, et al. Intracoronary autologous mononucleated bone marrow cell infusion for acute myocardial infarction: results of the randomized multicenter BONAMI trial. Eur Heart J (2011) 32:1748-57. doi:10.1093/eurheartj/ehq455

31. Assmus B, Rolf A, Erbs S, Elsasser A, Haberbosch W, Hambrecht R, et al. Clinical outcome 2 years after intracoronary administration of bone marrow-derived progenitor cells in acute myocardial infarction. Circ Heart Fail (2010) 3(1):89-96. doi:10.1161/circheartfailure.108.843243

32. Perin EC, Silva GV, Henry TD, Cabreira-Hansen MG, Moore WH, Coulter SA, et al. A randomized study of transendocardial injection of autologous bone marrow mononuclear cells and cell function analysis in ischemic heart failure (FOCUS-HF). Am Heart J (2011) 161(6):1078.e-87.e. doi:10.1016/j. ahj.2011.01.028

33. Hirsch A, Nijveldt R, van der Vleuten PA, Tijssen JGP, van der Giessen WJ, Tio RA, et al. Intracoronary infusion of mononuclear cells from bone marrow or peripheral blood compared with standard therapy in patients after acute myocardial infarction treated by primary percutaneous coronary intervention: results of the randomized controlled HEBE trial. Eur Heart J (2011) 32:1736-47. doi:10.1093/eurheartj/ehq449

34. Traverse JH, Henry TD, Ellis SG, Pepine CJ, Willerson JT, Zhao DXM, et al. Effect of intracoronary delivery of autologous bone marrow mononuclear cells 2 to 3 weeks following acute myocardial infarction on left ventricular function: the late TIME randomized trial. JAMA (2011) 306(19):2110-9. doi:10.1001/ jama.2011.1670

35. Leistner DM, Fischer-Rasokat U, Honold J, Seeger FH, Schachinger V, Lehmann R, et al. Transplantation of progenitor cells and regeneration enhancement in acute myocardial infarction (TOPCARE-AMI): final 5 -year results suggest long-term safety and efficacy. Clin Res Cardiol (2011) 100(10):925-34. doi:10.1007/s00392-011-0327-y

36. Traverse JH, Henry TD, Pepine CJ, Willerson JT, Zhao DXM, Ellis SG, et al. Effect of the use and timing of bone marrow mononuclear cell delivery on left ventricular function after acute myocardial infarction: the TIME randomized trial. JAMA (2012) 308(22):2380-9. doi:10.1001/jama.2012.28726

37. Antonitsis P, Anastasiadis K, Koliakos G, Vaitsopoulou C, Kouzi-Koliakou K, Doumas A, et al. Intramyocardial implantation of autologous bone marrow-derived stem cells combined with coronary artery bypass grafting in patients with ischemic cardiomyopathy: a pilot study. Hippokratia (2012) 16(4):366-70.

38. Perin EC, Willerson JT, Pepine CJ, Henry TD, Ellisy SG, Zhao DXM, et al. Effect of transendocardial delivery of autologous bone marrow mononuclear cells on functional capacity, left ventricular function, and perfusion in chronic heart failure. JAMA (2012) 307(16):1717-26. doi:10.1001/jama.2012.418

39. Surder D, Manka R, Lo Cicero V, Moccetti T, Rufibach K, Soncin S, et al. Intracoronary injection of bone marrow-derived mononuclear cells early or 
late after acute myocardial infarction: effects on global left ventricular function. Circulation (2013) 127(19):1968-79. doi:10.1161/circulationaha.112.001035

40. van Berlo JH, Kanisicak O, Maillet M, Vagnozzi RJ, Karch J, Lin S-CJ, et al. c-kit+ cells minimally contribute cardiomyocytes to the heart. Nature (2014) 509(7500):337-41. doi:10.1038/nature13309

41. Sultana N, Zhang L, Yan J, Chen J, Cai W, Razzaque S, et al. Resident c-kit(+) cells in the heart are not cardiac stem cells. Nat Commun (2015) 6:8701. doi:10.1038/ncomms 9701

42. Liu Q, Yang R, Huang X, Zhang H, He L, Zhang L, et al. Genetic lineage tracing identifies in situ kit-expressing cardiomyocytes. Cell Res (2016) 26(1):119-30. doi:10.1038/cr.2015.143

43. Nadal-Ginard B, Ellison GM, Torella D. Absence of evidence is not evidence of absence: pitfalls of cre knock-ins in the c-kit locus. Circ Res (2014) 115(4):415-8. doi:10.1161/circresaha.114.304676

44. Dominici M, Le Blanc K, Mueller I, Slaper-Cortenbach I, Marini F, Krause D, et al. Minimal criteria for defining multipotent mesenchymal stromal cells. The international society for cellular therapy position statement. Cytotherapy (2006) 8(4):315-7. doi:10.1080/14653240600855905

45. Schu S, Nosov M, Flynn LO, Shaw G, Treacy O, Barry F, et al. Immunogenicity of allogeneic mesenchymal stem cells. J Cell Mol Med (2012) 16(9):2094-103. doi:10.1111/j.1582-4934.2011.01509.x

46. Amado LC, Saliaris AP, Schuleri KH, St. John M, Xie J-S, Cattaneo S, et al. Cardiac repair with intramyocardial injection of allogeneic mesenchymal stem cells after myocardial infarction. Proc Natl Acad Sci U S A (2005) 102(32):11474-9. doi:10.1073/pnas.0504388102

47. Williams AR, Hare JM. Mesenchymal stem cells: biology, pathophysiology, translational findings, and therapeutic implications for cardiac disease. Circ Res (2011) 109:923-40. doi:10.1161/CIRCRESAHA.111.243147

48. Ye N-S, Zhang R-L, Zhao Y-F, Feng X, Wang Y-M, Luo G-A. Effect of 5 -azacytidine on the protein expression of porcine bone marrow mesenchymal stem cells in vitro. Geno Prot Bioinfo (2006) 4(1):18-25. doi:10.1016/ S1672-0229(06)60012-0

49. Antonitsis P, Ioannidou-Papagiannaki E, Kaidoglou A, Papakonstantinou C. In vitro cardiomyogenic differentiation of adult human bone marrow mesenchymal stem cells. The role of 5-azacytidine. Interact Cardiovasc Thorac Surg (2007) 6:593-7. doi:10.1510/icvts.2007.157875

50. Li X, Yu X, Lin Q, Deng C, Shan Z, Yang M, et al. Bone marrow mesenchymal stem cells differentiate into functional cardiac phenotypes by cardiac microenvironment. J Mol Cell Cardiol (2007) 42:295-303. doi:10.1016/j. yjmcc.2006.07.002

51. Xu W, Zhang X, Qian H, Zhu W, Sun X, Hu J, et al. Mesenchymal stem cells from adult human bone marrow differentiate into a cardiomyocyte phenotype in vitro. Exp BiolMed (2004) 229(7):623-31. doi:10.1177/153537020422900706

52. Martin-Rendon E, Sweeney D, Lu F, Girdlestone J, Navarrete C, Watt SM. 5-Azacytidine-treated human mesenchymal stem/progenitor cells derived from umbilical cord, cord blood and bone marrow do not generate cardiomyocytes in vitro at high frequencies. Vox Sang (2008) 95:137-48. doi:10.1111/j.1423-0410. 2008.01076.x

53. Rose RA, Jiang H, Wang X, Helke S, Tsoporis JN, Gong N, et al. Bone marrow-derived mesenchymal stromal cells express cardiac-specific markers, retain the stromal phenotype, and do not become functional cardiomyocytes in vitro. Stem Cells (2008) 329:2884-92. doi:10.1634/stemcells.2008-0329

54. Hatzistergos KE, Quevedo H, Oskouei BN, Hu Q, Feigenbaum GS, Margitich IS, et al. Bone marrow mesenchymal stem cells stimulate cardiac stem cell proliferation and differentiation: novelty and significance. Circ Res (2010) 107:913-22. doi:10.1161/circresaha.110.222703

55. Gnecchi M, Zhang Z, Ni A, Dzau VJ. Paracrine mechanisms in adult stem cell signalling and therapy. Circ Res (2008) 103:1204-19. doi:10.1161/ circresaha.108.176826

56. Hare JM, Fishman JE, Gerstenblith G, Velazquez DLD, Zambrano JP, Suncion VY, et al. Comparison of allogeneic vs autologous bonemarrowderived mesenchymal stem cells delivered by transendocardial injection in patients with ischemic cardiomyopathy: the POSEIDON randomized trial. JAMA (2012) 308(22):2369-79. doi:10.1001/jama.2012.25321

57. Mathiasen AB, Qayyum AA, Jørgensen E, Helqvist S, Fischer-Nielsen A, Kofoed KF, et al. Bone marrow-derived mesenchymal stromal cell treatment in patients with severe ischaemic heart failure: a randomized placebocontrolled trial (MSC-HF trial). Eur Heart J(2015) 36(27):1744-53. doi:10.1093/ eurheartj/ehv136
58. Guijarro D, Lebrin M, Lairez O, Bourin P, Piriou N, Pozzo J, etal. Intramyocardial transplantation of mesenchymal stromal cells for chronic myocardial ischemia and impaired left ventricular function: results of the MESAMI 1 pilot trial. Int J Cardiol (2016) 209:258-65. doi:10.1016/j.ijcard.2016.02.016

59. Chen SL, Fang WW, Ye F, Liu YH, Qian J, Shan SJ, et al. Effect on left ventricular function of intracoronary transplantation of autologous bone marrow mesenchymal stem cell in patients with acute myocardial infarction. Am J Cardiol (2004) 94(1):92-5. doi:10.1016/j.amjcard.2004.03.034

60. Hare JM, Traverse JH, Henry TD, Dib N, Strumpf RK, Schulman SP, et al. A randomized, double-blind, placebo-controlled, dose-escalation study of intravenous adult human mesenchymal stem cells (prochymal) after acute myocardial infarction. J Am Coll Cardiol (2009) 54(24):2277-86. doi:10.1016/j. jacc.2009.06.055

61. Karantalis V, DiFede DL, Gerstenblith G, Pham S, Symes J, Zambrano JP, et al. Autologous mesenchymal stem cells produce concordant improvements in regional function, tissue perfusion, and fibrotic burden when administered to patients undergoing coronary artery bypass grafting: the prospective randomized study of mesenchymal stem cell therapy in patients undergoing cardiac surgery (PROMETHEUS) trial. Circ Res (2014) 114:1302-10. doi:10.1161/ circresaha.114.303180

62. Lee JW, Lee SH, Youn YJ, Ahn MS, Kim JY, Yoo BS, et al. A randomized, open-label, multicenter trial for the safety and efficacy of adult mesenchymal stem cells after acute myocardial infarction. J Korean Med Sci (2014) 29(1):23-31. doi:10.3346/jkms.2014.29.1.23

63. Heldman AW, DiFede DL, Fishman JE, Zambrano JP, Trachtenberg BH, Karantalis V, et al. Transendocardial mesenchymal stem cells and mononuclear bone marrow cells for ischemic cardiomyopathy: the TAC-HFT randomized trial. JAMA (2014) 311(1):62-73. doi:10.1001/jama.2013.282909

64. Beltrami AP, Barlucchi L, Torella D, Baker M, Limana F, Chimenti S, et al. Adult cardiac stem cells are multipotent and support myocardial regeneration. Cell (2003) 114:763-76. doi:10.1016/S0092-8674(03)00687-1

65. Messina E, Angelis LD, Frati G, Morrone S, Chimenti S, Fiordaliso F, et al. Isolation and expansion of adult cardiac stem cells from human and murine heart. Circ Res (2004) 95:911-21. doi:10.1161/01.res.0000147315.71699.51

66. Nadal-Ginard B, Ellison GM, Torella D. The cardiac stem cell compartment is indispensable for myocardial cell homeostasis, repair and regeneration in the adult. Stem Cell Res (2014) 13:615-30. doi:10.1016/j.scr.2014.04.008

67. Smith AJ, Lewis FC, Aquila I, Waring CD, Nocera A, Agosti V, et al. Isolation and characterization of resident endogenous c-Kit+ cardiac stem cells from the adult mouse and rat heart. Nat Protoc (2014) 9(7):1662-81. doi:10.1038/ nprot.2014.113

68. Miyamoto S, Kawaguchi N, Ellison GM, Matsuoka R, Shin’ka T, Kurosawa H. Characterization of long-term cultured c-kit+ cardiac stem cells derived from adult rat hearts. Stem Cells Dev (2010) 19(1):105-16. doi:10.1089/scd.2009.0041

69. Ellison GM, Vicinanza C, Smith AJ, Aquila I, Leone A, Waring CD, et al. Adult c-kit(pos) cardiac stem cells are necessary and sufficient for functional cardiac regeneration and repair. Cell (2013) 154:827-42. doi:10.1016/j.cell.2013.07.039

70. Hong KU, Guo Y, Li Q-H, Cao P, Al-Maqtari T, Vajravelu BN, et al. C-kit+ cardiac stem cells alleviate post-myocardial infarction left ventricular dysfunction despite poor engraftment and negligible retention in the recipient heart. PLoS One (2014) 9(5):e96725. doi:10.1371/journal.pone.0096725

71. Kawaguchi N, Smith AJ, Waring CD, Hasan MK, Miyamoto S, Matsuoka R, et al. C-kit(pos) GATA-4 high rat cardiac stem cells foster adult cardiomyocyte survivial through IGF-I paracrine signalling. PLoS One (2010) 5(12):e14297. doi:10.1371/journal.pone.0014297

72. Ellison GM, Torella D, Dellegrottaglie S, Perez-Martinez C, de Prado AP, Vicinanza $C$, et al. Endogenous cardiac stem cell activation by insulin-like growth factor-1/hepatocyte growth factor intracoronary injection fosters survival and regeneration of the infarcted pig heart. J Am Coll Cardiol (2011) 58(9):977-86. doi:10.1016/j.jacc.2011.05.013

73. Bolli R, Chugh AR, D'Amario D, Loughran JH, Stoddard MF, Ikram S, et al. Cardiac stem cells in patients with ischaemic cardiomyopathy (SCIPIO): initial results of a randomised phase 1 trial. Lancet (2011) 378:1847-57. doi:10.1016/S0140-6736(11)61590-0

74. Chugh AR, Beache GM, Loughran JH, Mewton N, Elmore JB, Kajstura J, et al. Administration of cardiac stem cells in patients with ischemic cardiomyopathy: the SCIPIO trial surgical aspects and interim analysis of myocardial function and viability by magnetic resonance. Circulation (2012) 126:54-64. doi:10.1161/circulationaha.112.092627 
75. Keith MCL, Tang X-L, Tokita Y, Li Q-H, Ghafghazi S, Moore J IV, et al. Safety of intracoronary infusion of 20 million c-kit positive human cardiac stem cells in pigs. PLoS One (2015) 10(4):e0124227. doi:10.1371/journal.pone. 0124227

76. Makkar RR, Smith RR, Cheng K, Malliaras K, Thomson LEJ, Berman D, et al. Intracoronary cardiosphere-derived cells for heart regeneration after myocardial infarction (CADUCEUS): a prospective, randomised phase 1 trial. Lancet (2012) 379:895-904. doi:10.1016/S0140-6736(12)60195-0

77. Malliaras K, Makkar RR, Smith RR, Cheng K, Wu E, Bonow RO, et al. Intracoronary cardiosphere-derived cells after myocardial infarction: evidence of therapeutic regeneration in the final 1-year results of the CADUCEUS trial (CArdiosphere-derived aUtologous stem CElls to reverse ventricUlar dySfunction). J Am Coll Cardiol (2014) 63(2):110-22. doi:10.1016/j.jacc.2013.08.724

78. Tan J-J, Carr CA, Stuckey DJ, Ellison GM, Messina E, Giacomello A, et al. Isolation and expansion of cardiosphere-derived stem cells. Curr Protoc Stem Cell Biol (2011) 16:2C.3.1-2C.3.12. doi:10.1002/9780470151808. $\mathrm{sc} 02 \mathrm{c} 03 \mathrm{~s} 16$

79. Wang B, Borazjani A, Tahai M, Curry AL, Simionescu DT, Guan J, et al. Fabrication of cardiac patch with decellularized porcine myocardial scaffold and bone marrow mononuclear cells. J Biomed Mater Res A (2010) 94(4):1100-10. doi:10.1002/jbm.a.32781

80. Davis DR, Zhang Y, Smith RR, Cheng K, Terrovitis J, Malliaras K, et al. Validation of the cardiosphere method to culture cardiac progenitor cells from myocardial tissue. PLoS One (2009) 4(9):e7195. doi:10.1371/journal. pone. 0007195

81. Smith RR, Barile L, Cho HC, Leppo MK, Hare JM, Messina E, et al. Regenerative potential of cardiosphere-derived cells expanded from percutaneous endomyocardial biopsy specimens. Circulation (2007) 115:896-908. doi:10.1161/CIRCULATIONAHA.106.655209

82. Carr CA, Stuckey DJ, Tan JJ, Tan SC, Gomes RSM, Camelliti P, et al. Cardiosphere-derived cells improve function in the infarcted rat heart for at least 16 weeks - an MRI study. PLoS One (2011) 6(10):e25669. doi:10.1371/ journal.pone. 0025669

83. Johnston PV, Sasano T, Mills K, Evers R, Lee S-T, Smith RR, et al. Engraftment, differentiation, and functional benefits of autologous cardiosphere-derived cells in porcine ischemic cardiomyopathy. Circulation (2009) 120:1075-83. doi:10.1161/CIRCULATIONAHA.108.816058

84. Chimenti I, Smith RR, Li T-S, Gerstenblith G, Messina E, Giacomello A, et al. Relative roles of direct regeneration versus paracrine effects of human cardiosphere-derived cells transplanted into infarcted mice. Circ Res (2010) 106:971-80. doi:10.1161/CIRCRESAHA.109.210682

85. Makkar R, Schatz R, Traverse J, Hamer A, Beattie K, Smith RR, et al., editors. Allogeneic heart stem cells to achieve myocardial regeneration (ALLSTAR): the one year phase I results. AHA Scientific Conference. Chicago, IL: Circulation (2014).

86. Loffredo FS, Steinhauser ML, Gannon J, Lee RT. Bone marrow-derived cell therapy stimulates endogenous cardiomyocyte progenitors and promotes cardiac repair. Cell Stem Cell (2011) 8:389-98. doi:10.1016/j. stem.2011.02.002

87. Hatzistergos KE, Saur D, Seidler B, Balkan W, Breton M, Valasaki K, et al. Stimulatory effects of MSCs on cKit+ cardiac stem cells are mediated by SDF1/CXCR4 and SCF/cKit signaling pathways. Circ Res (2016) 119:921-30. doi:10.1161/circresaha.116.309281

88. Suzuki G, Iyer V, Lee T-C, Canty JM Jr. Autologous mesenchymal stem cells mobilize cKit+ and CD133- bone marrow progenitor cells and improve regional function in hibernating myocardium. Circ Res (2011) 109:1044-54. doi:10.1161/CIRCRESAHA.111.245969

89. Williams AR, Hatzistergos KE, Addicott B, McCall F, Carvalho D, Suncion V, et al. Enhanced effect of combining human cardiac stem cells and bone marrow mesenchymal stem cells to reduce infarct size and to restore cardiac function after myocardial infarction. Circulation (2013) 127:213-23. doi:10.1161/ circulationaha.112.131110

90. Karantalis V, Suncion-Loescher VY, Bagno L, Golpanian S, Wolf A, Sanina C, et al. Synergistic effects of combined cell therapy for chronic ischemic cardiomyopathy. J Am Coll Cardiol (2015) 66(18):1990-9. doi:10.1016/j.jacc. 2015.08.879

91. Kostin S, Popescu LM. A distinct type of cell in myocardium: interstitial Cajal-like cells (ICLCs). J Cell Mol Med (2009) 13(2):295-308. doi:10.1111/j.1582-4934.2008.00668.x
92. Popescu LM, Manole CG, Gherghiceanu M, Ardelean A, Nicolescu MI, Hinescu ME, et al. Telocytes in human epicardium. JCell Mol Med (2010) 14(8):2085-93. doi:10.1111/j.1582-4934.2010.01129.x

93. Gherghiceanu M, Manole CG, Popescu LM. Telocytes in endocardium: electron microscope evidence. JCell Mol Med (2010) 14(9):2330-4. doi:10.1111/j.1582-4934.2010.01133.x

94. Zhou Q, Wei L, Zhong C, Fu S, Bei Y, Huica RI, et al. Cardiac telocytes are double positive for CD34/PDGFR-alpha. J Cell Mol Med (2015) 19(8): 2036-42. doi:10.1111/jcmm.12615

95. Bani D, Formigli L, Gherghiceanu M, Faussone-Pellegrini MS. Telocytes as supporting cells for myocardial tissue organization in developing and adult heart. J Cell Mol Med (2010) 14(10):2531-8. doi:10.1111/j.1582-4934. 2010.01119.x

96. Zhao B, Chen S, Liu J, Yuan Z, Qi X, Qin J, et al. Cardiac telocytes were decreased during myocardial infarction and their therapeutic effects for ischaemic heart in rat. JCell Mol Med (2013) 17(1):123-33. doi:10.1111/j.1582-4934.2012.01655.x

97. Zhao B, Liao Z, Chen S, Yuan Z, Yilin C, Lee KK, et al. Intramyocardial transplantation of cardiac telocytes decreases myocardial infarction and improves post-infarcted cardiac function in rats. J Cell Mol Med (2014) 18(5):780-9. doi: $10.1111 / \mathrm{jcmm} .12259$

98. Gherghiceanu M, Popescu LM. Cardiomyocyte precursors and telocytes in epicardial stem cell niche: electron microscope images. J Cell Mol Med (2010) 14(4):871-7. doi:10.1111/j.1582-4934.2010.01060.x

99. Brade T, Kumar S, Cunningham TJ, Chatzi C, Zhao X, Cavallero S, et al. Retinoic acid stimulates myocardial expansion by induction of hepatic erythropoietin which activates epicardial Igf2. Development (2011) 138(1):139-48. doi:10.1242/dev.054239

100. Wang J, Cao J, Dickson AL, Poss KD. Epicardial regeneration is guided by cardiac outflow tract and Hedgehog signalling. Nature (2015) 522(7555):226-30. doi:10.1038/nature14325

101. Winter EM, van Oorschot AAM, Hogers B, van der Graaf LM, Doevendans PA, Poelmann RE, et al. A new direction for cardiac regeneration therapy: application of synergistically acting epicardium-derived cells and cardiomyocyte progenitor cells. Circulation (2009) 2(6):643-53. doi:10.1161/ circheartfailure.108.843722

102. Winter EM, Grauss RW, Hogers B, van Tuyn J, van der Geest R, LieVenema $\mathrm{H}$, et al. Preservation of left ventricular function and attenuation of remodeling after transplantation of human epicardium-derived cells into the infarcted mouse heart. Circulation (2007) 116:917-27. doi:10.1161/ CIRCULATIONAHA.106.668178

103. Latham N, Ye B, Jackson R, Lam B-K, Kuraitis D, Ruel M, et al. Human blood and cardiac stem cells synergize to enhance cardiac repair when cotransplated into ischemic myocardium. Circulation (2013) 128:105-12. doi:10.1161/circulationaha.112.000374

104. Campagnolo P, Cesselli D, Al Haj Zen A, Beltrami AP, Krankel N, Katare R, et al. Human adult vena saphena contains perivascular progenitor cells endowed with clonogenic and proangiogenic potential. Circulation (2010) 121(15):1735-45. doi:10.1161/CIRCULATIONAHA.109. 899252

105. Katare R, Riu F, Mitchell K, Gubernator M, Campagnolo P, Cui Y, et al. Transplantation of human pericyte progenitor cells improves the repair of infarcted heart through activation of an angiogenic program involving micro-RNA-132. Circ Res (2011) 109(8):894-906. doi:10.1161/ CIRCRESAHA.111.251546

106. Avolio E, Meloni M, Spencer HL, Riu F, Katare R, Mangialardi G, et al. Combined intramyocardial delivery of human pericytes and cardiac stem cells additively improves the healing of mouse infarcted hearts through stimulation of vascular and muscular repair. Circ Res (2015) 116:e81-94. doi:10.1161/CIRCRESAHA.115.306146

107. Nowbar AN, Mielewczik M, Karavassilis M, Dehbi HM, Shun-Shin MJ, Jones S, et al. Discrepancies in autologous bone marrow stem cell trials and enhancement of ejection fraction (DAMASCENE): weighted regression and meta-analysis. BMJ (2014) 348:g2688. doi:10.1136/bmj.g2688

108. Fisher SA, Doree C, Mathur A, Martin-Rendon E. Meta-analysis of cell therapy trials for patients with heart failure. Circ Res (2015) 116(8):1361-77. doi:10.1161/CIRCRESAHA.116.304386

109. Afzal MR, Samanta A, Shah ZI, Jeevanantham V, Abdel-Latif A,Zuba-SurmaEK, et al. Adult bone marrow cell therapy for ischemic heart disease: evidence 
and insights from randomized controlled trials. Circ Res (2015) 117:558-75. doi:10.1161/CIRCRESAHA.114.304792

110. Menasché P, Vanneaux V, Hagège A, Bel A, Cholley B, Cacciapuoti I, et al. Human embryonic stem cell-derived cardiac progenitors for severe heart failure treatment: first clinical case report. Eur Heart J (2015) 36(30):2011-7. doi:10.1093/eurheartj/ehv189

111. Madonna R, Van Laake LW, Davidson SM, Engel FB, Hausenloy DJ, Lecour S, et al. Position paper of the European Society of Cardiology Working Group cellular biology of the heart: cell-based therapies for myocardial repair and regeneration in ischemic heart disease and heart failure. Eur Heart $J$ (2016) 37(23):1789-98. doi:10.1093/eurheartj/ehw113

112. Ott HC, Matthiesen TS, Goh S-K, Black LD, Kren SM, Netoff TI, et al. Perfusion-decellularized matrix: using nature's platform to engineer a bioartificial heart. Nat Med (2008) 14(2):213-21. doi:10.1038/ $\mathrm{nm} 1684$

113. Lu TY, Lin B, Kim J, Sullivan M, Tobita K, Salama G, et al. Repopulation of decellularized mouse heart with human induced pluripotent stem cell-derived cardiovascular progenitor cells. Nat Commun (2013) 4:2307. doi: $10.1038 /$ ncomms 3307

114. Guyette JP, Charest JM, Mills RW, Jank BJ, Moser PT, Gilpin SE, et al. Bioengineering human myocardium on native extracellular matrix. Circ Res (2016) 118:56-72. doi:10.1161/CIRCRESAHA.115.306874

Conflict of Interest Statement: JT received a research grant from CryoCord Sdn Bhd. All funders have no role in manuscript writing and funding this project. The authors declare that the research was conducted in the absence of any commercial or financial relationships that could be construed as a potential conflict of interest.

Copyright $\odot 2017$ Leong, Ng, Ellison-Hughes and Tan. This is an open-access article distributed under the terms of the Creative Commons Attribution License (CC BY). The use, distribution or reproduction in other forums is permitted, provided the original author(s) or licensor are credited and that the original publication in this journal is cited, in accordance with accepted academic practice. No use, distribution or reproduction is permitted which does not comply with these terms. 